\title{
Covid-19 Pandemic; Is This an Opportunity for an Educational Big-Bang?
}

\author{
Maria Karadimou \\ Aristotle University of Thessaloniki \\ Greece \\ Kostis Tsioumis \\ Aristotle University of Thessaloniki \\ Greece
}

Received: Sep. 7, $2021 \quad$ Accepted: Oct. 4, $2021 \quad$ Published: November 1, 2021

doi:10.5296/jse.v11i4.19015 URL: https://doi.org/10.5296/jse.v11i4.19015

\begin{abstract}
This article intends to investigate the impact of the pandemic on the Greek educational community and the opportunity to review the existing educational system. It consists of 4 main axes. The first part presents the pandemic chronicle to the educational community, the second analyses the challenges that the members of the educational community were called to face, the third analyses the pandemic as an opportunity to review the existing educational system, while the latter summarizes the main implications of the above. There are several reasons to review the Greek education system, most importantly the unequal provision of learning opportunities to students from low socio-economic backgrounds. The article comes to raise the question of whether the pandemic is an opportunity to review the educational system and provide equal learning opportunities for all. This article came to highlight the role of participants in the educational process and the challenges they faced with due to emergency.
\end{abstract}

Keywords: covid-19, pandemic, educational system review, equal learning opportunities, Greek school, education 


\section{Introduction}

In December 2019, public health is receiving a strong blow worldwide. A new corona virus (SARS-CoV-2), known to the public as COVID-19, emerged from Wuhan, China, triggering the onset of a serious respiratory infection. The rapid development within three months, led the World Health Organization (World Health Organization, Regional Office of Europe, 2020) on March 12 to declare COVID-19 as a pandemic, since the virus had 118,000 cases in 114 different countries, removing the life of 4,291 people worldwide. This resulted in a global information campaign for the protection of public health, with the most well-known measures being the frequent hand washing, keeping distance of 1-3 meters between people, avoiding touching the eyes, nose, as well as timely medical intervention whenever there are symptoms (World Health Organization, Regional Office of Europe, 2020). But apart from the public health sector, the rapid spread of COVID-19 worldwide has forced all countries to take decisive action in various areas that will help alleviate this pandemic.

One of the main measures taken is the suspension of educational institutions. According to data from Unesco (2020a), the operation of educational institutions is suspended due to COVID-19 pandemic for the first time on 10/04/2020. Viewing the global picture, it affected about 190 countries worldwide and concerned numerically 1,578,657,884 students. Specifically in Greece, it has affected a total of 2,204,532 students, of which 152,462 attend kindergarten, 649,246 primary school, 667,797 secondary education, and 735,027 higher education.

Is this evidence capable of showing us that covid-19 can be an opportunity for an educational Bing Bang?

The Bing Bang theory in the science of astrophysics is known as the explosion that took place from a point with minimal mass but large amounts of energy, releasing it and creating matter in the universe.

This term is now reworded with its metaphorical dimension to frame the phenomenon of covid-19. More specifically, the sudden appearance of the pandemic is likened to an explosion, as the focal point of the global community, causing many changes in all areas of life. Of course, the educational community could not emerge unscathed from all this "explosion", because it relies for centuries on the in-person contact of students with their teachers. Covid-19 abruptly and instantly forced the educational community to revise and adapt to new data, which it was often called upon to create from scratch. The covid-19 therefore functioned for education as a "Bing bang" that came to release its existing energy and from this to create a new educational "material" in the universe.

In this article, which is based on a conceptual knowledge rather than an empirical knowledge, we focus on the presentation of circulars and instructions given to the educational community during the period February 2020- May 2021 regarding the management of the pandemic in schools in Greece. Through a short presentation of the decisions taken for key areas of education, an attempt is made to inform the reader of the management of the pandemic in the Greek educational system. Of course, the article is not limited to the simple presentation of 


\section{Macrothink}

the above data but takes a critical approach to the issue.

It presents the challenges that arose in the field of education due to the covid-19 phenomenon and proposes it's later use as an opportunity to review the existing educational system. The purpose of the article is to show that the proper use of the "big bang" phenomenon covid-19 can serve as an aid in formulating a new educational policy for a school that will listen to the needs of all children.

After all, the pandemic brought to light both challenges and new opportunities in education. It highlighted the need to review the existing student-teacher relationship in order to work more supportively for their students and to try to eliminate all the negative consequences that arose due to the crisis. In addition, it is at the same time an opportunity for student training in the field of independent learning, and of the teachers in the most effective use of technological tools aimed at better teaching (Unesco, 2020b).

\section{Literature Framework}

\subsection{The chronicle of the pandemic for the educational community}

Due to the emergency situations, the Ministry of Education had to be able in a very short period to carry out a very demanding project, and to take a series of initiatives, which would be the guidelines for the entire educational community. This resulted in the issuance of constantly new circulars to provide information of the updated decisions.

\subsubsection{Operation of schools}

The Government announced that in the context of protection of public health against coronavirus COVID-19 and following a recommendation of the National Committee for Public Health Protection, the temporary suspension until April 10,2020 of the educational structures (JMD D1a/GP.oik.20021/2020) with extension until May 10 (JMD D1a/GP.oik.24343/2020). Specifically, the operation of all public and private schools of all levels, tuition centers and any kind of educational structure was interrupted, with the potentiality of covering new material and not only repetitions for which they were informed subsequently (covid19.gov.gr, 2020c).

After a reassessment of the epidemiological situation, instructions were sent to the school units on May 6, 2020 (JMD 51888/GD4/2020) for their reopening, which were accompanied by information notes to: a) School principals, b) Teachers, c) Parents/guardians, d) Students. The information material contained information on topics such as: a) COVID-19 and the symptoms of the disease, b) modes of transmission, c) self-protection and third-party protection measures and d) measures that need to be taken in case of occurrence of the disease at school. For the smooth reopening of schools, a series of instructions are proposed by experts for the safety of students and teachers (distance education, mask, sanitation, ventilation e.t.c) (covid19.gov.gr, 2020d).

The above instructions were followed by an announcement on May 7, for the gradual reopening of the educational structures, following a unanimous recommendation of the committee of experts. Specifically, it was decided from May 5, 2020 the operation of the 


\section{Ml Macrothink}

Journal of Studies in Education

ISSN 2162-6952

2021, Vol. 11, No. 4

Educational and Counseling Support Centers (KESY), from May 11, the beginning of courses for the High School graduates, and from May 18, for the rest of the classes of the High School and of the Secondary School.

Tutoring centers and language centers followed the gradual reopening of the respective educational level. Finally, JMD D1a/GP.oik.28237/2020 pointed out that excursions, visits, events, student and teacher exchange programs, and the operation of libraries were prohibited. In addition, a separate JMD 27731/2020 was issued for the safe transport of students, at half the fullness of school buses, ventilation and disinfection, while for the transport of students by taxi it was required the use of mask. On May 18, the Reopening of Supporting Teaching for the school year 2019-2020 was decided, until June 12, 2020.

On May 27 was decided the reopening of the primary education schools, and the special education and training schools (JMD 63314/GD4/2020). It provided recommendations, such as feeding by delivering packaged meals, observing high hygiene standards, using the dining area (keeping distances, and in small groups of students), taking care of the thorough cleaning and disinfection of the feeding areas. To limit student interaction, systematic segregation was suggested to avoid overcrowding. It is possible to adjust the program schedule, breaks and on-call hours, while there is no gathering of students in the courtyard before the start of the schedule. In addition, to avoid overcrowding in the school units, where for the first time the registration of the country's toddlers was implemented electronically through the Single Digital Portal of the Public Administration (gov.gr) (JMD 53128/D1, 2020). On June 1 announced the regulation of absences of primary education students, in case they have a statement of parents that they, or the child belong to an increased risk group (JMD F.7/FM/63728/GD4/2020, JMD DIDAD/F.64/346/9011/2020). The academic year closed with an announcement on July 13 where the beginning of the new school year will take place earlier, and more specifically on September 7, 2020, so teachers can have the opportunity to repeat and fill any gaps that arose from the suspension of educational units due to the coronavirus (covid19.gov.gr, 2020e).

After the increase of the epidemiological burden in the country, it was decided (JMD 151978/GD4/2020) to start distance learning again between November 16-30, 2020 with teaching duration 40 minutes for High and Secondary school and 30 minutes for Primary School and Kindergartens (covid19.gov.gr, 2020f). The suspension of operation was extended from December 13, 2020 until January 07, 2021 (JMD D1a/GP.oik.80189/2020).

Following the recommendation of the committee was decided the beginning of the in-person education for the Primary Education students was defined, while the Secondary units continued to be suspended until January 18, 2021(JMD D1a/GP.oik.1293/2021). The decision was extended until January 24, 2021(JMD D1a/GP.oik.3060/2021).

For the lively operation of the schools, a new JMD D1a/GP.oik.969/2021 was issued which provided instructions for the possibility of different arrival and departure times of students, to avoid overcrowding. On February 1, a JMD D1a/GP.oik.8378/2021 issued that defined the in-person operation of secondary schools, but only in areas where the epidemiological burden allowed it. 


\section{NI Macrothink}

Journal of Studies in Education

ISSN 2162-6952

2021, Vol. 11, No. 4

Additional instructions were given on April 08,2021, regarding the in-person operation of all High Schools of the country from April 12, 2021, for their safe operation (different breaks, particular measures for adapted operation of canteens, computer labs, use of musical instruments, etc.) (covid19.gov.gr, 2021).

On May 10, 2021 (JMD D1a/GP.oik.29114/2020) the return of the first and second grade students to the classrooms was defined with statement of self-diagnostic test with parallel application of the existing measures.

\subsubsection{Special Education}

It is worth mentioning that distance synchronous and asynchronous education was provided for students with disabilities and/or special educational needs, with the main purpose of maintaining the educational relationship and contact, between teachers and students. Regarding the provision of counseling and support services to students the operation of KESY was suspended when the physical presence of students was required, but the provision of remote counseling support for parents and students continued.

On November 16, 2020, when the closing of the school units was announced again (JMD D1a/GP.oik.72989/2020), along with the beginning of distance education, a differentiation was observed regarding students with disabilities and/or special educational needs. The Special education units were decided to continue to operate in-person throughout the pandemic.

\subsubsection{Digital Benefits}

To meet the need for distance education, the Ministry of Education made available to the teaching staff three forms of distance learning: Synchronous, Asynchronous, and Educational Television. The synchronous education was applied in real time in Primary schools, starting from March 24, 2020 until April 3, 2020, where students connected to a digital classroom through the platform of the Ministry and attended their courses. The whole process was coordinated by the school principals in communication with the parents. The asynchronous education based on the teacher's effort to create material, such as learning material and a training schedule that students could access at any time. This form of education was addressed to all students of Primary, Secondary, and High Schools. Finally, the Educational Television was provided from March 30, 2020, daily at 10 a.m. at the state television channel for the primary school students courses (covid19.gov.gr, 2020a).

An important decision was announced on April 08, 2020 where the request of the Ministry of Education and the Ministry of Digital Governance to telephone companies was accepted, and free access would be provided to all students for online courses, starting on April 08, 2020 (covid19.gov.gr, 2020b).

On December 28, 2020, a decision was issued on "Start of action". It is a free, rapid teacher training in distance education to cultivate knowledge and digital skills in pedagogical and didactic approaches, with the support of synchronous digital media.

On March 17, 2021 (JMD 30746/DG8/2021) the Digital Care program was announced to 
support families with students to purchase technological equipment, by providing them 200-euro vouchers.

\subsubsection{Promotion exams / regulation of absences}

New decisions (JMD 52826/D2/2020, JMD F4/53112/D4/2020) issued on May 9 regarding the school year 2019-2020, which will not conduct promotional and graduation examinations of students of Secondary and High schools. On May 20 (JMD 52826/D2, 2020) students informed that those who will have to contest sports for the national exams, their preparation is allowed (covid19.gov.gr, 2020d). The end of the academic year for secondary education was set on June 12, 2020.

Moreover (JMD DIDAD/F.64/341/9188/2020) the absences could be arranged in case the parents or guardians provided a statement that they belonged to a vulnerable group.

On April 22, 2021 it was announced that no promotional and graduation exams would conduct after a suggestion from the Institute of Educational Policy. The school year extended until June 25 for Kindergartens and Primary Schools and June 11 for Secondary and High schools. Finally, the start of National Exams for the General high schools was set to June 14, and for the vocational High Schools to June 15.

\subsubsection{Synchronous distance education}

From May 18, (JMD 57233/Y1/2020) the units that are still temporarily banned for in-person, can provide synchronous remote education. The units that operate, but there are students who stay at home for health reasons had the possibility of simultaneous transmission of their lesson. This could be achieved by disabling the recording / storage feature, where a locked link was sent exclusively to each student. In this case, they could watch only the teacher and the board and only at the time of learning process but not of the examination.

With the beginning of the new educational year, a decision was issued on September 15, according to which until the end of the school year 2020-2021 and while the risk of spreading the coronavirus SARS-COV-2 remained, the primary and secondary schools were obliged to provide synchronous distance education to students who cannot attend with physical presence the educational process. Specifically, it referred to a) students whose school units were in a state of temporary suspension or prohibition of operation, b) students who were unable to attend the educational process in-person, because they belong to high-risk groups, living with a person or themselves being ill from COVID-19, or have undergone a molecular diagnostic test for coronavirus SARS-COV-2, awaiting the result.

\subsubsection{Vaccination of educational community}

One of the last measures taken for the protection of the educational community by covid-19 was the decision of March 16, 2021 entitled "Procedure for vaccination of Teachers, Special Education Personnel, Special Auxiliary staff (E.B.P.) and students (16 years and over) of the School Units of Special Education and Training" which refers to the priority of inclusion of the above in the program of the current vaccination period. In addition, on April 21, 2021 the online platform for vaccination opened for all teachers regardless age. 


\section{Findings}

At this point an attempt will be made to present the challenges that emerged in the educational community due to covid-19 reflecting the current situation in Greece. Then a critical approach follows, utilizing the covid-19 phenomenon as an "Educational Big Bang" by analyzing the research data so far.

\subsection{The challenges of the pandemic in the educational community}

The sudden closure of educational institutions resulted in schools, leaders-teachers, teachers, and students to adapt quickly and abruptly to new circumstances, as they had to deal with an unprecedented situation due to the pandemic. The issue of the students return to the classroom has been a constant topic of discussion for the past 1.5 years, both in media and society, due to conflicting arguments about the consequences of opening or closing of schools.

The truth is that now we are not able to have a complete picture of the long-term effects of the pandemic and the suspension of schools. Research on the effects of covid is still in its infancy, as challenges tend to increase over time (Harris,2020 - Huber \& Helm, 2020). However, it is clear from the reviews that there is an increased risk of developing symptoms of depression and anxiety (Guessoum et al., 2020), as social deprivation is thought to have a negative effect on young children due to the sensitive phase of their lives (Orben, Tomova and Blakemore, 2020). More specifically, according to the American Psychological Association (Kousoulis et al., 2020) the potential effects of covid-19 isolation are met in members of society, with feelings such as loneliness, anxiety, depression, and possible post-traumatic stress disorder. In addition, the World Health Organization, Mental Health Department (2020) noted that adults working with children, need to be careful about their behavior and emotions, so that children can use them as a guideline for managing their own emotions (Wong and Moorhouse, 2020).

The pandemic has further widened the already widespread educational inequalities associated with factors such as gender, disability, immigration, mother language, learning disabilities, or other sources of socio-economic disadvantages.

In all this, it is very important to consider that for some children, school is the only way out of their poverty, while it acts as a "safe haven" for them for a few hours of the day, from a troubled family environment (Lewis et.al., 2021). Of course, this does not mean that the challenges of distance education are limited only to students from low socio-economic backgrounds who may not have the necessary equipment and internet access. Challenges and many questions also arise for students with disabilities and/or special educational needs about whether they can cope with such a form of education.

This is evidenced by the findings of Unesco (2020b) where $40 \%$ of the world's poorest countries have failed to support disadvantaged students during recent months, while the consequences of school closures have been particularly detrimental to disadvantaged children 
and their families, and mostly for the students with learning difficulties and special needs.

Unfortunately, the phenomenon of the pandemic reveals a form of hidden social inequality, this of digital inequalities (Beaunoyer, Dupere and Guitton, 2020), where there are differences between the access of social groups to technology and their ability to acquire benefits by using it (Büchi, Festic and Latzer, 2018; DiMaggio and Hargittai, 2001; Hargittai, 2010).

The state was called upon to meet the challenge of overcoming the barrier of access to online learning for all children by providing electronic media in both equipment and Internet access levels. The agreement with the telecommunication companies not to charge data on distance education platforms was a good first step. Moreover, a limited number of students per school unit had the opportunity to borrow digital media from the ministry (private donations) if they proved low-income criteria, or the existence of special learning difficulties. A few months ago, a delayed decision was taken to provide a discount voucher to students, with which they can purchase digital equipment. Unfortunately, this provision delayed significantly, resulting a considerable amount of valuable time already lost for students from low social backgrounds who have been forced to attend their classes via mobile phone, or in some cases not at all. Furthermore, the whole issue of distance education is a particular challenge for teachers who do not feel familiar with technology but are called upon to provide education using online platforms, which they are trying to learn to handle.

As for the teachers, they were immediately called to apply distance education, utilizing their personal technological means, while in case they did not have any, they were called directly to the purchasing process. Finally, the training of teachers in distance education started much later, while they were already called in the last year to support their students daily. Azorìn (2020, p. 382) argued that the education systems should accept this "digital checkmate imposed".

Collectively, the literature on the impact of COVID-19 so far has addressed issues such as the challenges, difficulties, constraints faced by governments, institutions and all stakeholders (Zhang et al., 2020; Judd et al., 2020; Lucas, Nelson and Sims, 2020; Huber and Helm, 2020; Morgan, 2020; Kyriazis, et.al., 2020) with experiences, strategies, and potential innovations for distance education (Ferdig et al., 2020; Sangster, Stoner and Flood, 2020) as well as descriptions of how institutions and stakeholders became involved and adapted to the new pandemic conditions (Moorhouse, 2020; Zhang et al., 2020; Bao, 2020). Future research will show even more components of this complex phenomenon, so that we can better evaluate any decision-making.

According to Dyregrov et.al., (2020) students who were better informed, or informed from reliable sources, showed less stress than the others. In the research of Sepulveda-Escobar and Astrid Morrison (2020) on distance education, the findings showed that the opportunity for teachers to discover and learn new technologies had benefits which could work positively in their future careers. Finally, the findings of a small survey in Hong Kong showed that despite the difficult conditions of the pandemic, the motivation of teachers was strengthened, because they showed greater commitment to their teaching as they were called to face social 


\section{Al Macrothink}

uncertainty (Wong and Moorhouse, 2020).

\subsection{The pandemic as an opportunity to review the existing educational reality}

The debate over covid-19 is in a polarized state for opposing voices. On the one hand, people who see the new situation as an opportunity to break away from the old, and to align the entire educational community worldwide, and on the other hand, people who recall a quick return to the old, as they want to adapt the new data to the old their educational habits (Harris, 2020).

The truth is that the pandemic acted like Big Bang dismantling the school in the sense we knew it, but not the learning, which takes place through every form and space. Online learning previously was considered an option, and now has managed to define education worldwide (Harris, 2020). This highlights the rapid adaptation of all participants in the educational process to the new data.

All the above show how urgently all participants in the educational community were called upon to adapt to the new data. The ministry ensured the provision of several instructions and measures as quickly and efficiently as possible to coordinate all these actions, but without the real interest and love of students and teachers, nothing could have become a reality.

Reviewing the last year, we can see that the experience of covid-19 brought to light the professional skills of teachers, who in a very short time were called to adapt to the new data, to teach and support the work of students without themselves being trained in such practices, having an opportunity to raise their voice and demonstrate their knowledge and professionalism (Hill et.al., 2020).

In addition, distance education has shown another advantage, the opportunity given to children to become more independent as students, since it is true that education focuses mainly on the ways in which learning exists and not on the outcomes. Focusing on the lost knowledge while schools were closed, probably we are going blind on the real pandemic effects, such as the social distance that children are forced to experience in this tender age (Sahlberg, 2020).

The pandemic taught us how quickly data and constants can change. It offers us an opportunity to reflect on the short, medium, and long-term considerations of those who can formulate educational policy so that they can articulate fairer education systems in which all are able to make full use of their potential, regardless their origin (Chapman and Bell, 2020).

According to Unesco (2020b) there are four areas that need to be reformed in the curricula, and more specifically to be based on a logic of competence, to have a socio-constructivist perspective, to focus on students, and to put more emphasis on authentic learning situations. However, there is a significant disconnection between these defined curricula and the classroom reality.

By studying the phenomenon of the crisis positively, one can see an opportunity to review the education of teachers, and in particular issues related to racism, inequality, the development of new models of education (Hill, Rosehart, Helene and Sadhra, 2020). It is a window of 


\section{Macrothink}

adjustment to prioritize what really makes sense, human nature and interest between each other, which involves radical changes in school systems worldwide, so that societies now perceive and act differently (Sellars and Imig, 2020).

We are in the era that we must adapt and evolve due to necessity to the new data, so it is up to everyone, if eventually all this will be done for the benefit of society (Netolicky, 2020). Taking advantage of the pandemic, COVID-19 is a good opportunity to explore the potential benefits of the disruption, including a perspective that will provide the basis for critical research, student-centered practice and a pioneering specialization in international education (Beard, 2020). It teaches us that policies to be designed in the future should take seriously the balance of the natural and structured environment and be able to respond to universal values to prepare people for future risks due to pandemics (Kyriazis et.al., 2020). This leads us to think that the pandemic is an opportunity to reconsider the purpose of the school, to "create" students who will be able to make new worlds, as a result of their learning, people who will feel capable and function autonomously so that they can survive when the rules of their lives change (Sahlberg, 2020). In summary, the pandemic offers us the opportunity to see how we can better serve students in the future during such disorders (Yates et.al., 2020).

\section{Conclusion}

It is true that this is not the first time that humanity has been called upon to face a pandemic. If we take a historical look back, we will recall in the relatively recent past the Spanish flu (Taubenberger, Kash and Morens, 2019; Hays, 2005). However, something unprecedented is observed in this occasion, since for the first time the restriction of people from their work, schools and social life is accompanied by the overwhelming presence of technology in all aspects of his life (Guitton, 2020). This automatically implies addressing several challenges arising from this situation with the most critical of which being the provision of equal learning opportunities to all students.

More specifically, the Greek political leadership was called to act immedliately to be able to operate in this demanding endeavor. At first, school principals felt meteoric to manage a set of challenges related to school administration, the informing of teachers, students and parents, and the coordination of distance education. Interesting information is provided regarding the ability to utilize digital technologies from the 2018 data for the Programme of the International Student Assessment (PISA). Specifically, in 34\% of students, their school principal agreed that there was an effective online student support platform compared to $54 \%$ of the average in other countries (OECD, 2020). For their part, teachers were invited to work suddenly in a digital classroom and to utilize several digital tools with which they often came in contact for the first time. However, it is interesting to note that in $44 \%$ of students, their principals agreed that their school has effective professional resources to help teachers learn to use digital devices that are below the OECD average of $65 \%$ (OECD, 2020). The students at this tender age had to accept that they would participate in the educational process without seeing their friends, going to school, limiting all their extracurricular activities. For the needs of e-learning, equipment was required, where according to the findings of PISA in 2018, 89\% of students in Greece stated that they have a computer that could be used for the needs of 


\section{Al Macrothink}

their schoolwork, a percentage equal to the average of OECD, while a small differentiation is observed in students from low socio-economic layers at a rate of $76 \%$ compared to $78 \%$ of the average (OECD, 2020). Finally, the parents had to immediately resolve the issue of their work, so that they could be at home to help the children to manage this new reality as smoothly as possible, which at the same time could be a problem, because in case of telework of the parents, the need for computer use was increasing at the same time.

All the above show us that managing a crisis requires very immediate and coordinated actions to get it done in the best possible way. The truth is that Greek society having recently gone through a period of deep economic crisis, was not properly prepared to face such a demanding management. Nevertheless, both the participants in the educational community and the political management have shown in general context that with love and a lot of effort, it is possible to overcome and deal, as far as possible, any difficulties. The phenomenon of the pandemic highlighted something also important, the emergence of networks of cooperation, solidarity and volunteerism, namely the transition from the individual to a collective way of thinking, which is a good opportunity to review human capital more broadly (Azorin, 2020).

One thing is for sure, both schools and teachers, through their daily friction during this time with online education during the crisis, have been trained in methods that will facilitate dealing with similar future situations (Morgan, 2020). This leads us to the conclusion that the management of the pandemic has shown that it is ultimately in the hands of all of us, whether this crisis acts as a brake on the educational community, or as a lever for reviewing the provided education.

\section{References}

Azorín, C. (2020). Beyond COVID-19 supernova. Is another education coming?. Journal of Professional Capital and 381-390. https://doi.org/10.1108/JPCC-05-2020-0019

Bao, W. (2020). COVID-19 and Online Teaching in Higher Education: A Case Study of Peking University. Human Behavior and Emerging Technologies, 2(2), 113-115. https://doi.org/10.1002/hbe2.191

Beard, C. (2020). International education in New Zealand: contemplating a new dawn following COVID-19's darkest night. Higher Education Research and Development, 39(7), 1384-1387. https://doi.org/10.1080/07294360.2020.1825344

Beaunoyer, E., Dupéré, S., \& Guitton, M.J. (2020). COVID-19 and digital inequalities: Reciprocal impacts and mitigation strategies. Computers in human behavior, 111, 106424. https://doi.org/10.1016/j.chb.2020.106424

Büchi, M., Festic, N., \& Latzer, M. (2018). How social well-being is affected by digital inequalities. International Journal of Communication, 12(21), 3686-3706. https://doi.org/ $10.5167 /$ uzh-167385, 0 .

Chapman, C., \& Bell, I. (2020). Building back better education systems: equity and 
COVID-19. Journal of Professional Capital and Community, 5(3/4), 227-236. https://doi.org/10.1108/JPCC-07-2020-0055

covid19.gov.gr. (2020a). Distance school education [Online]. Available: https://covid19.gov.gr/ex-apostaseos-scholiki-ekpedefsi/ (May 5, 2021)

covid19.gov.gr (2020b). Free access to digital platforms for distance education from mobile networks [Online].

Available: https://covid19.gov.gr/choris-chreosi-apo-kinita-diktya-i-prosvasi-se-psifiakes-platformes-gia -tin-ex-apostaseos-ekpedefsi/ (May 5, 2021)

covid19.gov.gr (2020c). Coverage of taught material during e-learning [Online]. Available: https:/covid19.gov.gr/kalypsi-didachthisas-ylis-ke-kata-ti-diarkia-tis-tilekpedefsis/ (May 5, 2021)

covid19.gov.gr (2020d). Instructions for the operation of the sports facilities and the way of training of the candidates of national examinations, for their admission to the Higher Education [Online].

Available: https://covid19.gov.gr/odigies-gia-ti-litourgia-ton-athlitikon-egkatastaseon-ke-tou-tropou-pro poniseon-ton-ypopsifion-panelladikon-exetaseon-gia-tin-isagogi-tous-stis-scholes-tis-tritovat hmias-ekpedefsis/ (May 5, 2021)

covid19.gov.gr (2020e). First bell on September 7 [Online]. Available: https://covid19.gov.gr/proto-koudouni-stis-7-septemvriou/ (May 5, 2021)

covid19.gov.gr (2020f). Instructions related to distance education for the operation of secondary education structures as well as instructions for places of worship from Monday $9 / 11$

[Online].

Available:

https://covid19.gov.gr/odigies-pou-aforoun-stin-ex-apostaseos-ekpaidefsi-gia-ti-leitourgia-ton -ekpaideftikon-domon-defterovathmias-ekpaidefsis-kathos-kai-odigies-gia-tous-chorous-latre ias-apo-deftera-9-11/ (May 5, 2021)

covid19.gov.gr (2021). Useful questions and answers for the in-person reopening of High schools and the [Online]. Available: https://covid19.gov.gr/chrisimes-erotiseis-kai-apantiseis-gia-ti-dia-zosis-epanaleitourgia-ton-1 ykeion-kai-to-self-testing/ (May 28, 2021)

DiMaggio, P., \& Hargittai, E. (2001). From the "digital divide” to "digital inequality": Studying internet use as penetration increases [Online]. Center for Arts and Cultural Policy Studies, Princeton University, 15, 1-25. https://doi.org/10.1002/bem.20484 (March 12, 2021)

Dyregrov, A., Fjærestad, A., Gjestad, R., \& Thimm, J. (2020). Young People's Risk Perception and Experience in Connection with COVID-19. Journal of Loss and Trauma, 1-14. https://doi.org/10.1080/15325024.2020.1853974

Ferdig, R.E., Baumgartner, E., Hartshorne, R., Kaplan-Rakowski, R., \& Mouza, C. (2020). Teaching, technology, and teacher education during the COVID-19 pandemic: Stories from the field. Waynesville, NC, USA: Association for the Advancement of Computing in 
Education (AACE).

Guessoum, S.B., Lachal, J., Radjack, R., Carretier, E., Minassian, S., Benoit, L., \& Moro, M.R. (2020). Adolescent psychiatric disorders during the COVID-19 pandemic and lockdown. Psychiatry Research. 291. 113264. https://doi.org/10.1016/j.psychres.2020.113264

Guitton, M.J. (2020). Cyberpsychology research and COVID-19. Computers in Human Behavior. 2013 (29). 2756-2757. https://doi.org/10.1016/j.chb.2020.106357

Hargittai, E. (2010). Digital Na(t)ives? Variation in internet skills and uses among members of the "net generation. Sociological Inquiry. 80(1). 92-113. https://doi.org/ 10.1111/j.1475-682X.2009.00317.x.

Harris,A., \& Jones,M. (2020). COVID 19 - school leadership in disruptive times, School $\begin{array}{llll}\text { Leadership and } \quad \text { Management, } & \text { 243-247. }\end{array}$ https://doi.org/10.1080/13632434.2020.1811479

Hays, J.N. (2005). Epidemics and pandemics: Their impacts on human history. Santa Barbara: Abc-clio.

Hill, C., Rosehart, P., St.Helene, J., \& Sadhra, S. (2020). What kind of educator does the world need today? Reimagining teacher education in post-pandemic Canada. Journal of Education for Teaching, 46(4), 565-575. https://doi.org/10.1080/02607476.2020.1797439

Huber, S.G., \& Helm, C. (2020). COVID-19 and schooling: evaluation, assessment and accountability in times of crises - reacting quickly to explore key issues for policy, practice and research with the school barometer. Educational Assessment, Evaluation and Accountability, 32, 237-270. https://doi.org/10.1007/s11092-020-09322-y

Judd, J., Rember, B.A., Pellegrini, T., Ludlow, B., \& Meisner, J. (2020). This is Not Teaching: The Effects of COVID-19 on Teachers [Online]. Available: https://www. socialpublishersfoundation.org/knowledge_base/this-is-notteaching-the-effects-of-covid-19-o n-teachers (April 14, 2021)

Kousoulis, A., McDaid, S., Crepaz-Keay, D., Solomon, S., Lombardo, C., Yap, J., Weeks, L., O'Sullivan, C., Baird, R., Grange, R., Giugliano, T., Thorpe, L., Knifton, L., Rowland, M., Van Bortel, T., John, A., Lee, S., Morton, A., \& Davidso, G. (2020). The COVID-19 Pandemic, Financial Inequality and Mental Health [Online]. Mental Health Foundation. Available:

https://www.mentalhealth.org.uk/sites/default/files/MHF-covid-19-inequality-mental-healthbr iefing (March 12, 2021)

Kyriazis, A., Mews, G., Belpaire, E., Aerts, J., \& Malik, S.A. (2020). Physical distancing, children and urban health: The COVID-19 crisis' impact on children and how this could affect future urban planning and design policies. Cities and Health, 1-6. https://doi.org/10.1080/23748834.2020.1809787

Lewis, S.J., Munro, A.P., Smith, G.D., \& Pollock, A.M. (2021). Closing schools is not evidence based and harms children. Keeping schools open should be the UK's top priority. 


\section{Macrothink}

The BMJ, 372(521), 1-2. http://dx.doi.org/10.1136/bmj.n521

Lucas, M., Nelson, J., \& Sims, D. (2020). Schools' responses to Covid-19: Pupil engagement in remote learning. National Foundation for Educational Research, 1-40. Available: https://files.eric.ed.gov/fulltext/ED608590.pdf (March 15, 2021)

Moorhouse, B.L. (2020). Adaptations to a face-to-face initial teacher education course 'forced' online due to the COVID-19 pandemic. Journal of Education for Teaching, 1-3. https://doi.org/10.1080/02607476.2020.1755205

Morgan, H. (2020). Best practices for implementing remote learning during pandemic. The Clearing House: A Journal of Educational Strategies, Issues and Ideas, 93(3), 135-141. https://doi.org/10.1080/00098655.2020.1751480

Netolicky, D.M. (2020). School leadership during a pandemic: navigating tensions. Journal of Professional Capital and Community, 5(3/4), 391-395. https://doi.org/10.1108/JPCC-05-2020-0017

OECD (2020). School education during COVID -19: Were teachers and students ready? Greece.

Available:

https://www.oecd.org/education/Greece-coronavirus-education-country-note.pdf (October 1, 2021)

Orben, A., Tomova, L., \& Blakemore, S.J. (2020). The effects of social deprivation on adolescent development and mental health. The Lancet Child and Adolescent Health, 4(8), 634-640. https://doi.org/10.1016/S2352-4642(20)30186-3

Sahlberg, P. (2020). Will the pandemic change schools?. Journal of Professional Capital and Community, 5(3/4), 359-365. http://dx.doi.org/10.1108/JPCC-05-2020-0026

Sangster A., Stoner G., \& Flood B. (2020). Insights into accounting education in a COVID-19 world. Accounting Education, 29(5), 431-562. https://doi.org/10.1080/09639284.2020.1808487

Sellars, M., \& Imig S. (2020). The real cost of neoliberalism for educators and students. International Journal of Leadership in Education, 1-13. https://doi.org/10.1080/13603124.2020.1823488

Sepulveda-Escobar, P., \& Morrison, A. (2020). Online teaching placement during the COVID-19 pandemic in Chile: challenges and opportunities. European Journal of Teacher Education, 43(4), 587-607. https://doi.org/10.1080/02619768.2020.1820981

Taubenberger, J.K., Kash, J.C., \& Morens, D.M. (2019). The 1918 influenza pandemic: 100 years of questions answered and unanswered. Science translational medicine, 11(502), 1-15. https://doi.org/10.1126/scitranslmed.aau5485

Unesco (2020a). COVID-19. Education: From disruption to recovery [Online]. Available: https://en.unesco.org/covid19/educationresponse\#schoolclosures (March 15, 2021)

Unesco, (2020b). Education and COVID-19: challenges and opportunities [Online]. 


\section{Macrothink \\ Journal of Studies in Education \\ ISSN 2162-6952 2021, Vol. 11, No. 4}

Available:

https://en.ccunesco.ca/idealab/education-and-covid-19-challenges-and-opportunities (March $15,2021)$

Wong K., \& Moorhouse, B.L. (2020). The Impact of Social Uncertainty, Protests, and COVID-19 on Hong Kong Teachers, Journal of Loss and Trauma, 25(8), 649-655. https://doi.org/10.1080/15325024.2020.1776523

World Health Organization, Regional Office of Europe (2020). Coronavirus disease (COVID-19) pandemic [Online]. Available: https:/www.who.int/emergencies/diseases/novel-coronavirus-2019?gclid=EAIaIQobChMIwa jr28ni8AIVmamyCh3dCAo_EAAYASAAEgJRKPD_BwE (March 12, 2021)

Yates A., Starkey L., Egerton B., \& Flueggen F., (2020). High school students' experience of online learning during Covid-19: the influence of technology and pedagogy. Technology, Pedagogy and Education, 30(1), 59-73. https://doi.org/10.1080/1475939X.2020.1854337

Zhang, W., Wang, Y., Yang, L., \& Wang, C. (2020). Suspending classes without stopping learning: China's education emergency management policy in the COVID-19 Outbreak. Journal of Risk and Financial Management, 13(3), 1-6. https://doi.org/10.3390/jrfm13030055 